\title{
MIRIS - an adequate method to measure fortified breast milk?
}

\author{
Alexandra Kreissl", Valentina Zwiauer, Andreas Repa, Christoph Binder, Margarita Thanhaeuser, Angelika Berger, \\ Nadja Haiden
}

From 50th Workshop for Pediatric Research

Gottingen, Germany. 20-21 March 2014

\section{Introduction}

Human milk (HM) is unique and the gold standard for feeding neonates. HM contains insufficient quantity of protein for preterm infants. Therefore, a new supplement (Aptamil Protein $+{ }^{\circledR}$-Milupa/Danone) was developed.

\section{Aim}

The aim was to learn about the capability of MIRIS Human Milk Analyzer to measure the composition, particular of the protein content, in HM after addition of Human Milk Fortifier (HMF) and a bovine protein powder $\left(\mathrm{P}+{ }^{\circledR}\right)$.

\section{Methods}

Nutrient composition of HM was measured baseline, after fortification with commercial HMF (Aptamil 4.3\% FMS ${ }^{\circledR}$-Milupa/Danone and BEBA 5\%FM85 ${ }^{\circledR}$-Nestlé), and after addition of further protein $\left(\mathrm{P}+{ }^{\circledR}\right)$ in $0.5 \mathrm{~g}$ steps up to $4.0 \mathrm{~g} / 100 \mathrm{ml}$. Different milk processing types and the influence on MIRIS measurements was evaluated.

\section{Results}

Preanalytic testing: MIRIS was capable to measure bovine protein dissolved in water accurately. Impreciseness started after adding $0.5 \mathrm{~g} \mathrm{P}+{ }^{\circledR}$ to $\mathrm{HM}$-fortifier mixtures and revealed up to $20 \%$ difference after addition of 4.0g $\mathrm{P}+{ }^{\circledR}$. Native HM (FMS group, $\mathrm{n}=67$ ) contained in mean $1.1 \pm 0.3 \mathrm{~g}$ protein, $3.1 \pm 0.8 \mathrm{~g}$ fat, $6.6 \pm 0.3 \mathrm{~g}$ lactose, $11.7 \pm 0.8 \mathrm{~g}$ of dry mass and $59 \pm 10 \mathrm{kcal}$ per $100 \mathrm{ml} \mathrm{HM}$. After fortification of $\mathrm{HM}$ with $\mathrm{HMF}$ and $4.0 \mathrm{~g} \mathrm{P}+{ }^{\circledR} \mathrm{a}$ deviation in protein content of $1.0 \mathrm{~g}$ protein $/ 100 \mathrm{ml}$ in FMS ${ }^{\circledR}$ group and in $F M 85^{\circledR}$ group was observed. MIRIS underestimated protein content of HM fortified with

Department of Pediatrics, Division of Neonatology, Pediatric Intensive Care Medicine and Neuropediatrics, Medical University of Vienna, Vienna, Austria
HMF and $\mathrm{P}+{ }^{\circledR}$ mixtures $(\mathrm{p}<0.05)$. MIRIS underevaluated carbohydrates and energy content. Processing of HM had no effects on protein level. Lactationday correlated significantly with protein content $(\mathrm{p}<0.0001 ; \mathrm{r}=-, 4243)$.

\section{Conclusions}

MIRIS is an adjuvant tool to provide the actual nutrient composition of unfortified HM. MIRIS has the ability to measure solely bovine protein (in water) and human protein in HM. A combination of both types of protein generated imprecise results of protein content altogether. Processing had no effect on protein content. Protein significantly decreased with lactation period in preterm HM.

Published: 11 September 2014

\section{doi:10.1186/2194-7791-1-S1-A9}

Cite this article as: Kreissl et al:: MIRIS - an adequate method to

measure fortified breast milk? Molecular and Cellular Pediatrics 20141 (Suppl 1):A9

Submit your manuscript to a SpringerOpen ${ }^{\circ}$ journal and benefit from:

- Convenient online submission

- Rigorous peer review

- Immediate publication on acceptance

- Open access: articles freely available online

- High visibility within the field

- Retaining the copyright to your article

Submit your next manuscript at $>$ springeropen.com (c) 2014 Kreissl et al; licensee Springer This is an Open Access article distributed under the terms of the Creative Commons Attribution License (http://creativecommons.org/licenses/by/2.0), which permits unrestricted use, distribution, and reproduction in any medium, provided the original work is properly cited. 